\title{
PENGEMBANGAN IKM MAKANAN RINGAN OLAHAN DI KECAMATAN CIHAURBEUTI KABUPATEN CIAMIS
}

\author{
Maman Hilman $^{1}$, Qushayyi Hafidz Alhiyami ${ }^{2}$ \\ Maman Hilman, Qushayyi Hafidz Alhiyami \\ Teknik Industri, Universitas Galuh Ciamis \\ Jl. R.E. Martadinata No.150 Ciamis, Jawa Barat \\ hilmanmaman410@gmail.com ${ }^{1}$, alhiland98@gmail.com ${ }^{2}$
}

\begin{abstract}
Abstrak
Perkembangan sektor industri dalam pembangunan di Indonesia tidak terlepas dari peranan Industri Kecil Menengah (IKM). Kabupaten Ciamis merupakan kabupaten yang berada diujung selatan provinsi jawa barat yang juga memiliki peranan potensi IKM sebagai daya tarik peluang pengembangan yang mampu menghasilkan Industri Kecil Menengah (IKM) tersebut terdiri atas usaha kecil menengah sebanyak 91 dan 39 jenis usaha didominasi oleh yang menguasai sektor IKM dan perekonomian masyarakat dengan olahan makanan ringan khas. Penelitian ini bertujuan untuk: (1) Mengidentifikasi sektor basis yang ada di Kecamatan Cihaurbeuti menggunakan metode Location Quotient (LQ). Serta (2) Menentukan Strategi pengembangan dari sektor prioritas IKM Makanan Ringan Olahan di Kecamatan Cihaurbeuti menggunakan metode Analitycal Hierarchy Process (AHP)

Berdasarkan hasil pada analisis Location Quotient (LQ) diperoleh hasil yakni, terdapat tiga sektor IKM yang menjadi sektor basis di Kecamatan Cihaurbeuti. Dalam perhitungan LQ ini, IKM Makanan Ringan Olahan termasuk sektor basis dengan indeks LQ rata rata > 1yaitu 2,96. Berdasarkan hasil pada Analitical Hierarchy Process (AHP) dengan analisis menggunakan prinsip dekomposisi dan comparative judgement diperoleh strategi pengembangan IKM Makanan Ringan yaitu, pada Pertumbuhan Industri dengan tingkat kepentingan $51 \%$ dan untuk alternatif pengembangan industri yang menjadi fokus adalah Nilai Produksi dengan tingkat kepentingan $22 \%$.
\end{abstract}


an importance level of $51 \%$ and for alternative industrial development the focus is Production Value with an importance level of $22 \%$.

Key Word : SMI, Location Quotient (LQ), AHP.

\section{PENDAHULUAN}

Sektor perindustrian merupakan sektor yang berpotensi menghasilkan nilai tambah tertutama bagi banyak usaha dan bisnis. Nilai tambah tersebut antara lain adanya variasi produk yang beraneka ragam yang berkualitas yang dihasilkan industri untuk menarik konsumen, serta moderenisasi yang digunakan untuk menghasilkan profit yang sebesar-besarnya.

Perkembangan sektor industri dalam pembangunan di Indonesia tidak terlepas dari peranan Industri Kecil Menengah (IKM). Dengan demikian, upaya peningkatan pengembangan industri merupakan langkah yang tepat untuk memacu pertumbuhan ekonomi daerah dan juga untuk membuka kesempatan dan peluang kerja. Keberadaan IKM juga sebagai penopang ekonomi kerakyatan di suatu daerah setempat.

Kabupaten Ciamis merupakan kabupaten yang berada diujung selatan provinsi jawa barat yang juga memiliki peranan potensi pertanian dan masyarakat usaha, koperasi dan IKM sebagai daya tarik peluang pengembangan yang mampu menghasilkan pasar. Pada sebelum pemekaran Kota Banjar, Kabupaten ciamis dikategorikan daerah sedang tumbuh. Sedangkan pada pasca pemekaran kota banjar laju pertumbuhan perekonomian termasuk kategori relatif tertinggal. Peranan peningkatan struktur ekonomi dapat ditempuh dengan meningkatkan kontribusi sektor indutri sehingga memiliki nilai tambah yang lebih baik.

Kecamatan Cihaurbeuti merupakan daerah penghasil makanan ringan olahan yang tersebar keberbagai daerah di pulau jawa khususnya di Jawa Barat. Terhitung sejak bulan Oktober tahun 2017, Industri Kecil Menengah (IKM) tersebut terdiri atas usaha kecil menengah sebanyak 91 dan 39 jenis usaha didominasi oleh yang menguasai sektor IKM dan perekonomian masyarakat dengan olahan makanan ringan khas. Pada kenyataan nya potensi yang dimiliki industri ini belum sepenuhknya maksimal yang dapat berperan besar kepada masyakarat di Kecamatan Cihaurbeuti. Meskipun dapat membuka lapangan pekerjaan dan mata pencaharian bagi masyarakat, akan tetapi belum sepenuhnya bisa mencapai target harapan dan masih banyak hal yang perlu dibenahi.

Berdasarkan observasi yang dilakukan oleh penulis pada IKM Makanan Ringan Olahan di Kecamatan Cihaurbeuti, dapat diketahui beberapa masalah dan hambatan yang ditemui :

1. Variasi produk yang beraneka ragam yang dihasilkan dapat memenuhi kepuasan konsumen namun dari segi rasa masih monoton, sehingga diperlukan nya pengembangan (upgrade) lebih modern dengan jaman seperti rasa ataupun bahan baku tambahan dalam kemasan makanan tradisional.

2. Timbal balik keuntungan produk terhadap pekerja masih menggunakan sistem upah yang realtif belum mencapai UMR Kabupaten Ciamis, diharapkan dengan adanya pengembangan IKM Makanan Ringan Olahan ini selain menjaga kelestarian budaya daerah tetapi juga menjadi sumber penghasilan yang dapat memenuhi kebutuhan masyarakat.

3. Daya saing produk makanan ringan olahan memiliki kualitas yang bagus tetapi masih belum maksimal dibanding produk luar, sebab produk nya masih menggunakan proses pengolahan dan pengelolaan secara manual meskipun sebagian sudah menggunakan mesin. Sehingga ada kesalahan dalam segi ukuran yang tidak konsisten, ataupun proses pengemasan yang membuat produk tidak terjaga (bubuk).

Terkait pembahasan tersebut, bahwa pengembangan subsektor IKM Makanan Ringan Olahan diharapkan akan meningkat karena memberikan kontribusi lebih bagi pertumbuhan ekonomi serta kesejahteraan masyarakat sekitar di daerah Kecamatan Cihaurbeuti serta dapat memehuni kecukupannya, IKM makanan ringan olahan sendiri merupakan sebuah tuntutan untuk mengelola potensi yang dimilikinya.

Maman Hilman, Qushayyi Hafidz Alhiyami 


\begin{abstract}
Berdasarkan Permasalahan diatas, maka penelitian ini mengambil usulan topik "Pengembangan IKM Makanan Ringan Olahan di Kecamatan Cihaurbeuti Kabupaten Ciamis“
\end{abstract}

\section{TINJAUAN PUSTAKA}

\section{Location Quotient (LQ)}

Metode LQ untuk mengidentifikasi komoditas unggulan diakomodasi dari Miller \& Wright (1991), Isseman (1997), dan Ron Hood (1998). Menurut Hood (1998), Location Quotient (LQ) adalah suatu pengembangan ekonomi yang lebih sederhana dengan segala kelebihan dan keterbatasannya. Teknik LQ merupakan salah satu pendekatan yang umum digunakan dalam model ekonomi basis sebagai langkah awal untuk memahami sektor kegiatan yang menjadi pemacu pertumbuhan. LQ mengukur konsentrasi relatif atau derajat spesialisasi kegiatan ekonomi melalui pendekatan perbanding.

Pada penelitian ini, analisis LQ digunakan untuk menentukan perbandingan sektor - sektor yang ada di Kecamatan Cihaurbeuti (Regional) dengan Kabupaten Ciamis (Nasional). Adapun rumus LQ adalah sebagai berikut : (Rahmana;2012)

$$
L Q=\frac{\left(S_{i j} / S_{i}\right)}{(\operatorname{Sin} / S n)}
$$

Di mana :

Sij = Jumlah kapasitas produksi pada sektor i di daerah $\mathbf{J}$

$\mathrm{Si}=$ Jumlah total kapasitas produksi di daerah $\mathrm{J}$

Sin = Jumlah kapasitas produksi pada sektor i di daerah referensi $\mathrm{N}$

$S n=$ Jumlah total kapasitas produksi di daerah referensi $\mathrm{N}$

Terdapat tiga golongan nilai dari Location Quotient (LQ), yaitu sebagai berikut :

1) Jika LQ > 1, maka mengindikasikan bahwa sektor tersebut merupakan sektor unggulan atau sektor basis. Produk yang dihasilkan tidak hanya dapat memenuhi kebutuhan diwilayah saja, namun juga dapat untuk memenuhi kebutuhan wilayah lainnya. Artinya, sektor tersebut dapat dikembangkan sebagai penggerak perekonomian di Kecamatan Cihaurbeuti.

2) Jika LQ < 1, maka mengindikasikan bahwa suatu wilayah mempunyai spesialisasi yang rendah (non basis). Upaya yang mesti dilakukan oleh pemerintah adalah memasok produk dari luar daerah karena sektor non basis ini tidak dapat memenuhi kebutuhan daerahnya.

3) Jika $L Q=1$, maka mengindikasikan bahwa suatu wilayah mengalami Self sufficent (Spesialisasi sama). Ini juga berarti, hanya bisa memenuhi kebutuhan di Kecamatan Cihaurbeuti saja.

\section{Analitical Hierarchy Process (AHP)}

AHP adalah model pendukung keputusan yang dikembangkan oleh Thimas L. Saaty. Ciri analisis adalah menggunakan hirarki yang menguraikan permasalahan dalam satu kesatuan menjadi elemenelemen yang lebih sederhana. Hierarki pada analisis ini dibagi menjadi goal, skenario, sasaran, dan strategi. AHP merupakan teknik pengambilan keputusan secara matematis dengan mempertimbangkan aspek kualitatif maupun kuantitatif. Selain itu, faktor yang diperhatikan dalam metode AHP yaitu faktor persepsi, prefensi, pengalaman dan intuisi. (Bambang Permadi, 1992:10)

Pada AHP, yang diukur adalah rasio konsistensi dengan melihat indeks konsistensinya. Konsistensi yang diharapkan adalah yang mendekati sempurna agar menghasilkan keputusan yang mendekati valid. Demikian, pada penelitian ini tidak dilakukan uji validitas ataupun reliabilitas terhadap kuesioner AHP karena AHP mentolelir inkonsistensi. AHP diukur dengan Indeks Konsistensi (CI) dan Rasio Konsistensi (CR) dengan uraian sebagai berikut :

1. Menghitung Consistenscy Index (CI) dengan rumus :

$$
\mathrm{CI}=(\pi \operatorname{maks}-\mathrm{n}) /(\mathrm{n}-1)
$$

Keterangan :

$\mathrm{n}$ = banyaknya elemen

2. Menghitung Consistency Rasio (CR) dengn rumus :

Maman Hilman, Qushayyi Hafidz Alhiyami

Jurnal Ilmiah Teknologi Informasi Terapan

Volume 8, No 1, 15 Desember 2021 
$\mathrm{CR}=\mathrm{CI} / \mathrm{IR}$

Keterangan :

$$
\mathrm{IR}=\text { Index Random Consistency }
$$

Secara umum tingkatan konsistensi tertentu memang dibutuhkan dalam menentukan prioritas unutk mendapatkan hasilyang sah untuk itu dalam AHP nilai CR tidak boleh dari $10 \%$ atau 0,1 , kemudian dalam megolah hasil kuesioner AHP akan dilakukan dengan menggunakan aplikasi Expert Choice 11. Adapun prinsip yang mendasar pada perhitungan AHP yaitu :

\section{a. Dekomposisi}

pada tahapan ini, masalah yang diteliti dibagi menjadi sebuah hierarki. Tujuannya untuk mendifinisikan masalah dari yang umum sampai dengan yang khusus. Struktur hirarki tersebut berfungsi untuk membandingkan antara tujuan, kriteria, dan tingkatan alternatif. Bentuk struktur dekomposisi yakni:

Tingkatan pertama : tujuan (Goal)

Tingkatan kedua : kriteria

Tingkatan ketiga : alternatif

Adapun struktur hierarki AHP dapat digambarkan :

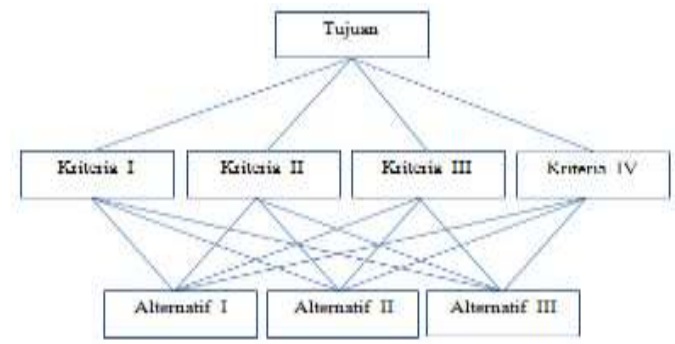

\section{Gambar 1. Struktur Hirarki}

\section{b. Comparative Judgement}

Comparative Judgement sering juga disebut sebagai penilaian kriteria atau alternatif, pada tahapan ini akan dibuat suatu perbandingan berpasangan dari semua elemen yang ada pada hierarki. Dengan dihasilkannya skala kepentingan pada tiap-tiap elemen. Penilaian yang dilakukan akan menghasilkan suatu angka yang nantinya akan dibandingkan untuk menhasilkan sebuah prioritas. Skala angka yang dibandingkan adalah satu sampai sembilan yang kemudian disusun utnuk

mendapatkan perbandingan berpasangan. Adapun skala perbandingan yang digunakan yakni:

Tabel 1. Skala Perbandingan AHP

\begin{tabular}{cl}
\hline \hline 1 & $\begin{array}{l}\text { Tujuan yang satu dengan yang lainnya } \\
\text { sama penting. }\end{array}$ \\
\hline 3 & $\begin{array}{l}\text { Tujuan yang satu sedikit lebih penting } \\
\text { (agak kuat) dibanding tujuan lainnya. }\end{array}$ \\
\hline 5 & $\begin{array}{l}\text { Tujuan yang satu sifatnya lebih penting } \\
\text { (lebih kuat pentingnya) dibanding tujuan } \\
\text { lainnya. }\end{array}$ \\
\hline 7 & $\begin{array}{l}\text { Tujuan yang satu sangat penting } \\
\text { dibanding tujuan yang lainnya. }\end{array}$ \\
\hline 9 & $\begin{array}{l}\text { Tujuan yang satu ekstrim pentingnya } \\
\text { dibanding tujuan lainnya. }\end{array}$ \\
\hline 2,4, & $\begin{array}{l}\text { Nilai tengah diantara dua nilai skor } \\
\text { penilaian di atas. }\end{array}$ \\
\hline \hline
\end{tabular}

\section{III.ANALISIS DAN PERANCANGAN}

III.1 Perancangan

Maman Hilman, Qushayyi Hafidz Alhiyami 


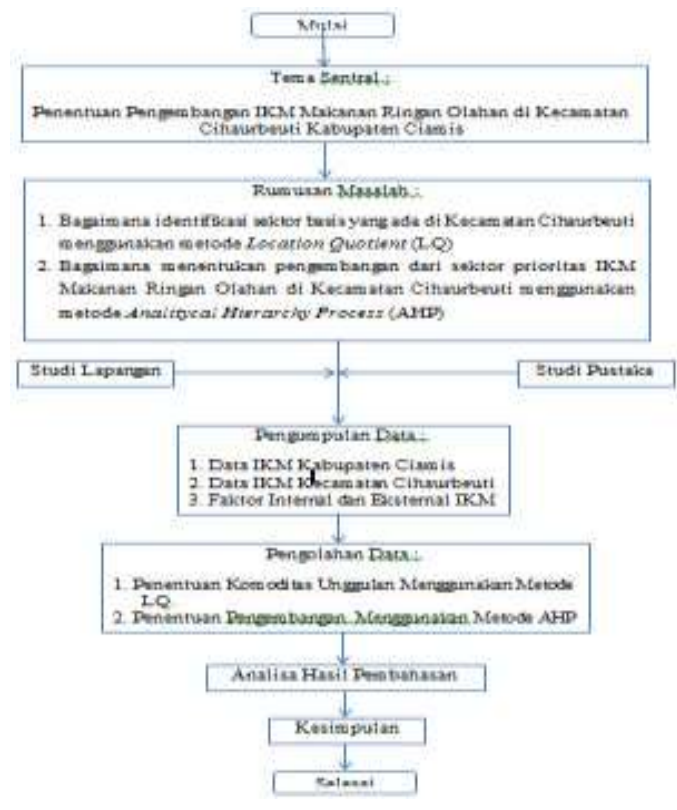

Gambar 2. Flow Chart Penelitian

Pengumpulan data yang dilakukan dalam penelitian ini didapatkan melalui :

1. Observasi. Yaitu teknik pengumpulan data yang dilakukan melalui pengamatan terhadap apa yang terjadi dilapangan. Observasi dialkukan di IKM Makanan Ringan Olahan utnuk mendapatkan data dan informasi mengenai kondisi IKM Makanan Ringan Olahan dan permasalahannya.

2. Wawancara. Yaitu teknik pengumpulan data dengan melakukan dengan tanya jawab serta bertatap muka secara langsung dengan pihak yang berkaitan dengan penelitian. Wawancara dilakukan kepada pengelola dan pegawai IKM Makanan Ringan Olahan dan pihak yang terkait dengan perusahaan untuk memperoleh data dan informasi mengenai pengembangan IKM

Metode dalam penelitian ini adalah metode Location Quotient (LQ) dan Analitical Hierarchy Process (AHP). Metode LQ digunakan untuk mengidentifikasi komoditas unggulan disuatu wilayah, LQ menyajikan perbandingan relatif antara kemampuan suatu sektor di daerah yang diselidiki (Kecamatan Cihaurbeuti) dengan kemampuan yang sama pada daerah yang diselidiki (Kabupaten Ciamis). AHP merupakan sebuah metode hirarki yang digunakan untuk menguraikan masalah dalam satu kesatuan menjadi elemen-elemen sederhana.

\section{III.2 Data}

1. Data IKM Kabupaten Ciamis

Tabel 2. Kapasitas Produksi IKM Kabupaten Ciamis

\begin{tabular}{llc}
\multicolumn{3}{c}{ Kabupaten Ciamis } \\
\hline No & \multicolumn{1}{c}{ Sektor } & $\begin{array}{c}\text { Rata-rata } \\
\text { (Tahun 2015-2019) }\end{array}$ \\
\hline 1 & Makanan Ringan Olahan & 15,135 \\
\hline 2 & Pengolahan daging & 1,224 \\
\hline 3 & Pengolahan tea & 240 \\
\hline 4 & Pengrajin Kayu & 42,543 \\
\hline 5 & Olahan Tempe dan Tahu & 2,800 \\
\hline 6 & Industri Tepung & 26,345 \\
\hline 7 & Minyak dan Gula Merah & 6,334 \\
\hline 8 & Tembakau & 215 \\
\hline \hline & Jumlah & 94,836 \\
\hline
\end{tabular}

Sumber: Diskoperindag Kab. Ciamis 2021

2. Data IKM Kecamatan Cihaurbeuti

Tabel 3. Kapasitas Produksi IKM Kecamatan Cihaurbeuti Kabupaten Ciamis

o Sektor $\quad \begin{gathered}\text { Rata-rata } \\ (2015-2019)\end{gathered}$

\begin{tabular}{lc}
\hline Makanan Ringan Olahan & 500 \\
\hline Pengolahan daging & 22 \\
\hline Pengolahan tea & 240 \\
\hline Pengrajin Kayu & 288 \\
\hline
\end{tabular}

Maman Hilman, Qushayyi Hafidz Alhiyami

Jurnal Ilmiah Teknologi Informasi Terapan

Volume 8, No 1, 15 Desember 2021 


\begin{tabular}{lc}
\hline Olahan Tempe dan Tahu & 6 \\
\hline Industri Tepung & 0 \\
\hline Minyak dan Gula Merah & 0 \\
\hline Tembakau & 0 \\
\hline \hline \multicolumn{1}{c}{ Jumlah } & 1,056 \\
\hline \hline
\end{tabular}

Sumber: Diskoperindag Kab. Ciamis 2021

\section{III.3 HASIL DAN PEMBAHASAN}

\section{III.3.1 Hasil Analisis Metode Location Quotient}

Hasil perhitungan Location Quotient (LQ) di Kecamatan Cihaurbeuti dalam rata-rata kurun waktu lima tahun (2015-2019) selengkapnya dapat dilihat pata tabel berikut :

Tabel 4. Hasil Perhitungan Metode LQ

\begin{tabular}{ccc} 
No & \multicolumn{1}{c}{ Sektor } & $\begin{array}{c}\text { Rata- } \\
\text { rata LQ }\end{array}$ \\
\hline \hline Makanan Ringan Olahan & 2.9650 \\
\hline Pengolahan daging & 1.6238 \\
\hline Pengolahan tea & 89.8024 \\
\hline Pengrajin Kayu & 0.6098 \\
\hline Olahan Tempe dan Tahu & 0.2395 \\
\hline Industri Tepung & 0.0000 \\
\hline Minyak dan Gula Merah & 0.0000 \\
\hline Tembakau & 0.0000 \\
\hline \hline
\end{tabular}

Berpacu pada hasil perhitungan LQ diatas, yang memiliki nilai LQ tertinggi ada pada sektor Pengolahan Tea dengan nilai LQ sebesar 89,80.
Namun pada penelitian ini, penenliti tidak berfokus pada sektor tersebut untuk ditentukan strategi pengembangan nya. Peneliti akan memfokuskan analisis pengembangan pada subsektor IKM Makanan Ringan Olahan dalam asumsi memiliki jumlah sektor IKM paling banyak di Kecamatan Cihaurbeuti Kabupaten Ciamis. Untuk itu meskipun bukan menunjukan sektor basis yang paling utama, maka akan dikembangkan lagi analisisnya agar kedepannya sektor IKM Makanan Ringan Olahan menjadi sektor unggulan di Kecamatan Cihaurbeuti pada masa yang akan datang. Hal ini dinilai IKM Makanan ringan sangat berperan penting bagi PRDB Kabupaten Ciamis dan mempunyai potensi untuk menguasai sektor IKM Khusus nya di Kecamatan Cihaurbeuti dan dapat bersaing dengan regional maupun nasional.

\section{III.3.2 Hasil Analisis Metode AHP}

Penentuan bobot tujuan kriteria subsektor prioritas dari IKM Makanan Ringan Olahan tingkat pertama yaitu menentukan tingkat kepentingan antar masing -masing tujuan kriteria. Adapun tujuan kriterianya yaitu ; Pertumbuhan Industri, Penyerapan Tenaga Kerja dan Peningkatan Daya Saing sebagai berikut :

Tabel 5. Hasil Perhitungan Bobot Tujuan AHP

\begin{tabular}{|c|c|c|c|}
\hline No & Kriteria & $\begin{array}{c}\text { Priority } \\
\text { Vector }\end{array}$ & Bobot $(\%)$ \\
\hline 1 & $\begin{array}{l}\text { Pertumbuhan } \\
\text { Industri }\end{array}$ & $\begin{array}{l}0,51 \\
0 *\end{array}$ & $51^{*}$ \\
\hline 2 & $\begin{array}{l}\text { Penyerapan } \\
\text { Tenaga Kerja }\end{array}$ & $\begin{array}{l}0,25 \\
6\end{array}$ & 25,6 \\
\hline 3 & $\begin{array}{l}\text { Peningkatan } \\
\text { Daya Saing }\end{array}$ & $\begin{array}{l}0,23 \\
4\end{array}$ & 23,4 \\
\hline
\end{tabular}

Keterangan : *=Bobot Terbesar

Consistency

Ratio $(C R)=0,02$

Sumber :Output AHP Expert Choice

Hasil Perhitungan didapatkan nilai $\mathrm{CR}=0,02<$ 0,1 hal ini menujukan bahwa matriks perbandingan berpasangan antar kriteria usdah konsisten.untuk

Maman Hilman, Qushayyi Hafidz Alhiyami 
menentukan pengembangan yang harus diprioritaskan dari IKM Makanan Ringan Olahan, tujuan kriteria yang paling penting untuk digunakan adalah Pertumbuhan industri dengan nilai bobot sebesar $51 \%$, lalu Penyerapan tenaga kerja 25,6\%, dan tPeningkatan daya saing 23,4\%.

Penentuan penetapan pengembangan prioritas dengan alternatifsetelah ditentukannya penetapan bobot kriteria, langkah selanjutnya adalah menggunakan bobot alternatif yang digunakan untuk memilih pengembangan prioritas IKM Makanan Ringan Olahan antara lain;

Tabel 6. Kriteria pertumbuhan industri dengan alternatif

\begin{tabular}{clccc}
\hline No & $\begin{array}{c}\text { Alternatif } \\
\text { Subsektor }\end{array}$ & $\begin{array}{c}\text { Priority } \\
\text { Vector }\end{array}$ & $\begin{array}{c}\text { Bobot } \\
(\%)\end{array}$ & $\begin{array}{c}\text { Ran } \\
\text { king }\end{array}$ \\
\hline \hline 1 & $\begin{array}{l}\text { Manajemen } \\
\text { Pengolahan }\end{array}$ & 0,169 & 16,2 & 3 \\
\hline 2 & $\begin{array}{l}\text { Teknologi } \\
\text { Pengolahan }\end{array}$ & 0,139 & 13,9 & 4 \\
\hline 3 & $\begin{array}{l}\text { Nilai } \\
\text { Produksi }\end{array}$ & 0,242 & 24,2 & 1 \\
\hline 4 & $\begin{array}{l}\text { Nilai Bahan } \\
\text { Baku }\end{array}$ & 0,127 & 12,7 & 5 \\
\hline 5 & $\begin{array}{l}\text { Nilai } \\
\text { Investasi }\end{array}$ & 0,211 & 21,1 & 2 \\
\hline 6 & Kualitas SDM & 0,112 & 11,2 & 6 \\
\hline \hline & Consistency Ratio(CR)=0,04 \\
Sumber :Output AHP Expert Choice &
\end{tabular}

Dari perhitungan AHP, didapatkan nilai CR perbandingan antara kriteria pertumbuhan industri terhadap alternatif sebesar $0,04<0,1$, hal ini menunjukan bahwa perbandingan berpasangan antar alternatif sudah konsisten.kemudian didapatkan alternatif prioritas tertinggi untuk kriteria pertumbuhan industri pada nilai produski dengan Priority Vector sebesar 0,242 atau dibobotkan sebesar $24,2 \%$.

Tabel 7. Kriteria penyerapan tenaga kerja dengan alternatif

\begin{tabular}{clccc}
\hline No & $\begin{array}{l}\text { Alternatif } \\
\text { Subsektor }\end{array}$ & $\begin{array}{c}\text { Priority } \\
\text { Vector }\end{array}$ & $\begin{array}{c}\text { Bobot } \\
(\%)\end{array}$ & $\begin{array}{c}\text { Ran } \\
\text { king }\end{array}$ \\
\hline \hline 1 & $\begin{array}{l}\text { Manajemen } \\
\text { Pengolahan }\end{array}$ & 0,134 & 13,4 & 3 \\
\hline 2 & $\begin{array}{l}\text { Teknologi } \\
\text { Pengolahan }\end{array}$ & 0,129 & 12,9 & 4 \\
\hline 3 & $\begin{array}{l}\text { Nilai } \\
\text { Produksi }\end{array}$ & 0,123 & 12,3 & 5 \\
\hline 4 & $\begin{array}{l}\text { Nilai Bahan } \\
\text { Baku }\end{array}$ & 0,077 & 7,7 & 6 \\
\hline 5 & $\begin{array}{l}\text { Nilai } \\
\text { Investasi }\end{array}$ & 0,210 & 21 & 2 \\
\hline 6 & $\begin{array}{l}\text { Kualitas } \\
\text { SDM }\end{array}$ & 0,325 & 32,5 & 1 \\
\hline \hline
\end{tabular}

Consistency Ratio $(C R)=0,09$

Sumber :Output AHP Expert Choice

Dari perhitungan AHP, didapatkan nilai CR perbandingan antara kriteria pernyerapan tenaga kerja terhadap alternatif sebesar $0,09<0,1$, hal ini menunjukan bahwa perbandingan berpasangan antar alternatif sudah konsisten.kemudian didapatkan alternatif prioritas tertinggi untuk kriteria penyerapan tenaga kerja pada kualitas SDM dengan Priority Vector sebesar 0,325 atau dibobotkan sebesar 32,5\%.

Tabel 8. Kriteria peningkatan daya saing dengan alternatif

\begin{tabular}{clccc}
\hline No & $\begin{array}{l}\text { Alternatif } \\
\text { Subsektor }\end{array}$ & $\begin{array}{c}\text { Priority } \\
\text { Vector }\end{array}$ & $\begin{array}{c}\text { Bobot } \\
(\%)\end{array}$ & $\begin{array}{c}\text { Ran } \\
\text { king }\end{array}$ \\
\hline 1 & $\begin{array}{l}\text { Manajemen } \\
\text { Pengolahan }\end{array}$ & 0,196 & 19,6 & 2 \\
\hline 2 & $\begin{array}{l}\text { Teknologi } \\
\text { Pengolahan }\end{array}$ & 0,163 & 16,3 & 4 \\
\hline 3 & $\begin{array}{l}\text { Nilai } \\
\text { Produksi }\end{array}$ & 0,252 & 25,2 & 1 \\
\hline 4 & $\begin{array}{l}\text { Nilai Bahan } \\
\text { Baku }\end{array}$ & 0,168 & 16,8 & 3 \\
\hline 5 & $\begin{array}{l}\text { Nilai } \\
\text { Investasi }\end{array}$ & 0,108 & 10,8 & 6 \\
\hline 6 & $\begin{array}{l}\text { Kualitas } \\
\text { SDM }\end{array}$ & 0,114 & 11,4 & 5 \\
\hline \hline
\end{tabular}

Maman Hilman, Qushayyi Hafidz Alhiyami

Jurnal Ilmiah Teknologi Informasi Terapan

Volume 8, No 1, 15 Desember 2021 
Consistency Ratio $(C R)=0,06$

Sumber :Output AHP Expert Choice

Dari perhitungan AHP, didapatkan nilai CR perbandingan antara kriteria peningkatan daya saing terhadap alternatif sebesar $0,06<0,1$, hal ini menunjukan bahwa perbandingan berpasangan antar alternatif sudah konsisten.kemudian didapatkan alternatif prioritas tertinggi untuk kriteria peningkatan daya saing pada nilai produksi dengan Priority Vector sebesar 0,252 atau dibobotkan sebesar 25,2\%.

\section{III.3.3 Pembahasan}

Berdasarkan hasil perhitungan LQ menunjukan bahwa yang menjadi komoditas unggulan adalah sektor pengolahan tea, namun dalam penelitian difokuskan pada sektor IKM Makanan Ringan Olahan dengan indeks LQ rata-rata $>1$ yaitu 2,96. Besarnya kontribudi sektor ini karena didukung banyaknya sektor IKM Makanan Ringan Olahan di Kecamatan Cihaurbeuti dan mam pu berada pada kapasitas ekspor sebanyak 511,000 Kg / Tahun. Artinya, sektor tersebut dapat dikembangkan sebagai sektor basis dan penumbuhan perekonomian di Kecamatan Cihaurbeuti Kabupaten Ciamis.

Perhitungan total rangking atau prioritas global berdasarkan seluruh pilihan kriteria yang dilakukan dalam menentukan pengembangan prioritas diperoleh faktor pilihan kriteria total dengan Metode AHP, yaitu : Berdasarkan perhitungan diperoleh hasil prioritas pengembangan yang dapat dilakukan pada sektor IKM Makanan Ringan Olahan di Kecamatan Cihaurbeuti Kabupaten Ciamis. Hasil perhitungan bobot kriteria, yang mempunya nilai paling besar dan kemudian dijadikan prioritas. Yakni pada kriteria Pertumbuhan Industri sebesar 51\% . Sedangkan untuk kriteria Penyerapan Tenaga Kerja merupakan prioritas kedua dengan bobot sebesar $25,7 \%$ dan yang menjadi prioritas terakhir yaitu pada kriteria Peningkatan Daya Saign dengan bobot sebesar 17,3\%. Untuk penentuan alternatif pengembangan subsektor nya didapatkan bobot dari masing- masing alternatif yang dpat di tentukan berdasarkan hasil perhitungan AHP Yakni pada alternatif Nilai Produksi sebesar
$22 \%$, kemudian alternatif kedua pada Nilai Investasi sebesar 18,6\%, kemudian alternatif ketiga pada Manajemen Pengolahan sebesar 16,8\%, kemudian alternatif keempat pada Kualitas SDM sebesar 15,7\%, dan alternatif kelima pada Teknologi Pengolahan sebesar 14,3\%, sedangkan alternatif yang berada pada prioritas terakhir yaitu pada Nilai Bahan Baku sebesar $12,7 \%$.

\section{KESIMPULAN DAN SARAN}

\section{1 Kesimpulan}

Berdasarkan analisis dan pembahasan yang telah dilakukan oleh penulis, maka diperoleh kesimpulan sebagai berikut :

1. Berdasarkan hasil pada analisis Location Quotient (LQ) diperoleh hasil yakni, terdapat tiga sektor IKM yang menjadi sektor basis di Kecamatan Cihaurbeuti. Dalam perhitungan LQ ini, IKM Makanan Ringan Olahan termasuk sektor basis dengan indeks LQ rata rata > 1 yaitu 2,96.

2. Berdasarkan hasil pada Analitical Hierarchy Process (AHP) dengan analisis menggunakan prinsip dekomposisi dan comparative judgement diperoleh strategi pengembangan IKM Makanan Ringan yaitu, pada Pertumbuhan Industri dengan tingkat kepentingan $51 \%$ dan untuk alternatif pengembangan industri yang menjadi fokus adalah Nilai Produksi dengan tingkat kepentingan $22 \%$. Maka dari itu, hal tersebut diharapkan menjadi fokus utama dalam pengembangan IKM makanan ringan olahan di Kecamatan Cihaurbeuti Kabupaten Ciamis.

\section{2 Saran}

Saran dari penulis untuk pemerintah setempat dan IKM Makanan Ringan Olahan di Kecamatan Cihaurbeuti Kabupaten Ciamis :

1. Pemerintah setempat diharapkan dapat memperkuat kemitraan antara dinas perindustrian ataupun pihak swata dengan pelaku industri makanan ringan olahan melalui peningkatan pertumbuhan industri berupa bentuk pengarahan masyarakat usaha kreatif dimana faktor ini mempengaruhi 
kemampuan suatu daerah dalam meningkatkan pertumbuhan ekonomi dan potensinya dengan melalui nilai produksi dari produk IKM Makanan Ringan Olahan.

2. IKM makanan ringan olahan diharapkan mengimbangi keselestarian buadaya produknya dengan modernisasi sehingga dapat meningkatkan kuantitas produksi maupun harga per unit komoditasnya.

\section{REFERENSI}

Adisasmita, Raharjo. (2013). Teori-teori Pembangunan Ekonomi. Yogyakarta. Graha Ilmu.

Divisi Industri, (2019). Daftar Potensi Industri Per Kecamatan Kabupaten Ciamis. Dinas Koperasi Dan Perdagangan Kabupaten Ciamis.

Linaria Marokana Sihotang, (2019). Analisis Strategi Perencanaan Pengambangan Subsektor Industri Pengolahan Di Kota Tangerang Selatan. Jakarta. UIN Syarif Hidayatullah

Rahmana, A., Iriani, Y., dan Oktarina, R, (2012), Startegi Pengembangan Usaha Kecil Menengah Sektor Industri Pengolahan, Jurnal Teknik Industri, Vol. 13, No.1, 14-21.

Soeyatno, R. F. (2019). Analasis Penentuan Sektor Unggulan Terhadap Perekonomian Wilayah Kota Bogor Provinsi Jawa Barat Tahun 20122016. Jurnal Semarak, 1(3), 1-19.

Saragih, J. P. (2019). Kinerja Industri Manufaktur di Provinsi-Provinsi Sumatera Tahun 2010-2015 [Manufacturing Industry Performance in Sumatra Provinces 2010-2015]. Jurnal Ekonomi \& Kebijakan Publik, 9(2), 131-146. 